\title{
Update on Chagas' disease in Mexico
}

\author{
Eric Dumonteil, Ph.D.(1)
}

\section{Dumonteil E. \\ Update on Chagas' disease \\ in Mexico.}

Salud Publica Mex 1999;41:322-327.

\begin{abstract}
A bstract
Chagas' disease, caused by the protozoan parasite Trypanosoma cruzi, represents a major public health problem in most of the American continent. As transmission of the parasite is being interrupted in most of South America, the disease remains endemic in various areas of Mexico. We review here some of the information gathered in recent years. Seroprevalence of T. cruzi infection in humans remains relatively high in some areas, and there has been a general increase in the number of chronic cases reported to health authorities in recent years. In fact, chronic chagasic cardiomyopathy appears to be affecting a large number of patients with heart disease, but many cases may be misreported because of the unspecific nature of the clinical symptoms. Epidemiological monitoring of vector and reservoir populations, as well as of human cases is helping focus on endemic areas, but a better coordination and development of these efforts is still needed. Recent studies of parasite biology are in agreement with previous work showing the great diversity of parasite characteristics, and support the need for a regional approach to this zoonosis. Strong and continuing support from health and academic authorities is thus still needed to further improve our understanding of Chagas' disease in Mexico and implement efficient control programs.
\end{abstract}

Key words: C hagas disease; Mexico

\author{
Dumonteil E. \\ Actualización sobre la enfermedad de Chagas \\ en México.
}

Salud Publica Mex 1999;41:322-327.

\section{Resumen}

La enfermedad de Chagas, causada por el parásito protozoario Trypanosoma cruzi, constituye un importante problema de salud pública en el continente americano. La transmisión del parásito se ha ido interrumpiendo en la mayor parte de A mérica del Sur, pero la enfermedad sigue siendo endémica en varias regiones de México. En este artículo se revisa la información más reciente so bre dicha enfermedad. La seroprevalencia de la infección por T. cruzi se ha mantenido a niveles relativamente altos en algunas regiones, y se observa un aumento general en el número de casos reportados a las autoridades de salud en los últimos años. La cardiomiopatía chagásica crónica parece afectar a muchos pacientes con enfermedad cardiaca, pero aparentemente muchos casos no se reportan debido a la ausencia de especificidad del cuadro clínico. El monitoreo epidemioló gico de las poblaciones de vectores y reservorios, así como de los casos humanos, contribuye a enfocar estudios en las zonas endémicas, pero se requiere de un mayor avance y coordinación de estos esfuerzos. Estudios sobre la biología del parásito coinciden con trabajos previos que demuestran la gran diversidad de las car acterísticas del parásito, y apoyan la necesidad de estudios regionales de esta zoonosis. Es necesario un fuerte apoyo continuo por parte de las autoridades de salud y académicos para enriquecer nuestro conocimiento sobre la enfermedad de Chagas en México y desarrollar programas eficaces de control.

Palabras clave: enfermedad de Chagas; México

(1) Laboratorio de Parasitología, Centro de Investigaciones Regionales Dr. Hideyo N oguchi, Universidad Autónoma de Yucatán, México.

Fecha de recibido: 4 de enero de 1999 - Fecha de aprobado: 26 de abril de 1999

Solicitud de sobretiros: Eric Dumonteil, Ph.D. Laboratorio de Parasitología Centro de Investigaciones Regionales Dr. Hideyo N oguchi, Universidad Autónoma de Yucatán. Av. Itzaes 490 con calle 59, 97000 Mérida,Yucatán, México.

E-mail: oliver@ tunku.uady.mx 
C hagas' disease, or American trypanosomiasis, represents a major public health problem in most of the American continent. The WHO estimates that 16-18 million people may currently be infected and up to 100 million may be at risk of infection in the continent. ${ }^{1}$ The disease is caused by Trypanosoma cruzi, a flagellate protozoan parasite, transmitted by hematophagous bug vectors from the Triatominae subfamily. ${ }^{2,3}$ T. cruzi can be transmitted to a wide variety of wild or domestic mammals acting as host and reservoir, and to humans. Because housing colonization by triatomines is a key factor influencing transmission of T. cruzi, Chagas' disease is directly associated with socioeconomic conditions, particularly with poor housing and deficient domestic hygiene. Natural transmission occurs when contact with contaminated triatomine feces allows entry of T. cruzi through skin lesions, mucosas or conjonctiva. Transmission through blood transfusion can also easily occur and is the second major mean of infection. ${ }^{4-6}$ Congenital transmission has also been reported. ${ }^{78}$ but its importance remains well below that of natural and transfusion-associated transmission.

\section{Overview of the disease}

The disease associated with T. cruzi infection is chronic, and causes severe disability. There are three main stages in humans. ${ }^{9}$ The acute stage, which appears shortly after infection, is characterized by a high parasitemia and a general inflammatory response (fever, headaches, peripheral edema, Romaña's sign) of variable intensity. Most patients do not remember the acute phase of the disease, which is often dismissed as a common febrile illness. Acute infection is succeeded by an asymptomatic intermediate stage that may last 5-40 years, during which the immune system appears able to reduce circulating trypanosomes to below microscopically detectable levels. The chronic phase of the disease develops in about 30-40\% of infected patients, ${ }^{9,10}$ and corresponds to the slow destruction of infected cells by the amastigote form of the parasite. ${ }^{11}$ The primary targets are the heart, and to a lesser extent the gut and nervous tissues, ${ }^{10}$ and clinical signs of myocarditis generally appear in patients aged between 30-50 years. Some cardiac alterations such as extrasystoles or atria ventricular blocks are observed with a relatively high frequency, but none is totally specific of chagasic cardiomyopathy. ${ }^{9,10,12-14}$ Autoimmune reactions have been implicated in the progression of the disease, due to the presence of cross-reactive antigens shared by heart tissues and T. cruzi, ${ }^{15-17}$ but their relevance to the development of the disease is still debated. ${ }^{18,19}$ This chronic phase of the disease is highly incapacitating, and may ultimately lead to cardiac failure and death.

The main drugs used for therapeutic treatment are nitrifurans and nitroimidazoles, but both are highly mutagenic and cause significant side effects, so that neither is licensed in Europe or in the USA. ${ }^{9}$ Their efficacy is also limited to the acute phase of the infection, and it is highly variable so that there is still controversial evidence that patients really benefit from such treatments..$^{10}$ A variety of new drugs is thus currently under development, ${ }^{20-24}$ and some appear to show promise. However, additional studies are necessary and it will be some time before new treatments become available. Vaccines are still out of reach, even though a great amount of research has allowed a better understanding of the immune mechanisms of the infection, ${ }^{25,26}$ and proved that the development of a vaccine is clearly possible.

To date, the most widely used control strategies have been based, on one hand, on the control of house infestation by triatomine using insecticide, associated with the promotion of housing improvement, to control natural transmission of the parasite. ${ }^{27-29}$ On the other hand, systematic screening of donated blood with serological tests has been developed, to eliminate transfusion-associated transmission. ${ }^{5}$ Such programs have received strong support in most South American countries, and proved highly successful in dramatically reducing the prevalence of the disease in the participating countries. Indeed, house infestation by triatomines was reduced from around $30 \%$ in the early 80 s to $5-10 \%$ in the early 90s in countries such as Argentina, Brazil or Chile, and the prevalence of human infections was concomitantly reduced from an average 5-25\% to levels of $0.2-5 \% .{ }^{1}$ Prevalence levels of seropositive samples in blood banks was similarly reduced from $5-25 \%$ to levels around 1-5\%. In most of these countries, both the vectorial and transfusional transmission of Chagas' disease are expected to be interrupted in the coming years, ${ }^{1}$ and Uruguay is the first country to have already achieved this goal. ${ }^{30}$

\section{Chagas' disease in Mexico}

In Mexico, information on the prevalence of Chagas's disease is scarce and the public health importance of the disease remains debated. ${ }^{31-33} \mathrm{~A}$ few entomological studies of the triatomine vectors have been carried out and have reported that 39 species of triatomine bugs were present in Mexico, of which 20 have been found naturally infected by T. cruzi, ${ }^{34,35}$ The species of major medical importance are Triatoma barberi, T. dimidiata, 
Rhodnius prolixus, T. p. mazzotti and T. p. pallidipennis. ${ }^{3}$ Prevalence of infection ranging from 16-18\% for domiciliary T. dimidiata in Yucatán, ${ }^{36}$ to 33\% for T. barberi, $50 \%$ for T. p. mazzotti and $18 \%$ for T. p. longipennis in Jalisco, ${ }^{37}$ and up to $70-92 \%$ for T. barberi and $90 \%$ for T. p. pallidipennis in Morelos ${ }^{35,38}$ have been reported. Feeding habits of some species such as T. dimidiata and T. barberi have been determined and include humans as a relatively frequent feeding source, $36,39,40$ clearly demonstrating the vectorial capacity of these species. Interestingly, infected triatomines have been recently reported in new localities, ${ }^{41}$ but it is not clear if this represents a potential extension of endemic areas, or if these localities had been overlooked previously.

A number of wild reservoirs have also been identified in Mexico, which include small rodent and marsupial species such as rats, mice or opossums, with some species being very specific to Mexico. Seroprevalence of $T$. cruzi infection in these reservoirs has been reported to vary between $8 \%$ to $62 \%$ according to species and regions. ${ }^{42-45}$ Together, these vector and reservoir studies clearly demonstrate that T. cruzi infection is a zoonosis endemic in many regions of Mexico. The importance of human infection and disease is, on the other hand, more difficult to establish.

The first cases of human infection in Mexico were reported in the 40s and 50s, and up to 1991, about 300 clinical cases of chronic Chagas's cardiomyopathy had been officially reported. On the other hand, Schofield estimated in 1985 that close to 4 million people could be infected in Mexico. ${ }^{46}$ In fact, epidemiological studies indicate a very heterogeneous distribution of the infection in the country with highly endemic rural areas with an average seroprevalence between 5-20\%, and virtually disease-free urban zones (table I). However, a major limitation of many of these studies is that a single serological test was used for diagnosis of infection (immunofluorescence, hemagglutination or ELISA being the most common), even though the WHO recommends the use of at least two methods for an accurate diagnosis. Important methodological differences, particularly in the choice of antigen ${ }^{47}$ also make difficult the comparison of the different studies. The most extensive and homogeneous study performed to date to determine the prevalence of human T. cruzi infection is the National Seroepidemiology Survey of 1987 (ENS, Encuesta Nacional de Seroepidemiología), which confirmed the irregular distribution of Chagas' disease in Mexico, with prevalence of infection ranging from $0.1 \%$ in the state of Jalisco up to $5.0 \%$ in the state of Chiapas, but also revealed prevalence levels much lower than what had been previously reported in regional studies. ${ }^{48}$ However, a major limitation of this large scale study was its poor coverage of rural areas, which, as rightly pointed out by the authors, may have lead to a significant underestimation of the actual prevalence of the infection. Nonetheless, it appears from these studies that there are geographic regions with a relatively high seroprevalence of $T$. cruzi infection in humans.

In addition, a number of studies in blood banks indicated a seropositivity among blood donors ranging from $0.3 \%$ in Mexico City, to $17.5 \%$ in Puebla (table II). Such levels are much higher than that of seropositivity to AIDS or hepatitis B viruses, for example. Also, because blood donors are usually considered a healthy group, seropositivity levels for T. cruzi would be expected to be somewhat higher in open populations. But again, some of these studies only used

Table I

Seroprevalence of human T. cruzi infection in SOME MEXican States (\%)

\begin{tabular}{|c|c|c|c|c|c|}
\hline State & $<1949$ & $1950-1969$ & $1970-1979$ & $1980-1989$ & $1990-1998$ \\
\hline Campeche & & & & $1.5^{48}$ & \\
\hline Chiapas & & & $43.0^{61}$ & $5.0^{48}$ & \\
\hline Guerrero & & $8.5^{61}$ & & $1.7^{48}$ & $1.7^{62}$ \\
\hline Michoacán & $8.3^{61}$ & $7.3^{63}$ & & $1.3^{48}$ & \\
\hline Morelos & & & & & $3.2^{64}$ \\
\hline \multirow[t]{4}{*}{0 axaca } & & & $8.5^{61}$ & $25.0^{65}$ & \\
\hline & & & $1.4^{61}$ & $33.0^{66}$ & \\
\hline & & & $16.0^{34}$ & $14.0^{50}$ & \\
\hline & & & & $4.5^{48}$ & \\
\hline Q uintana Roo & & & & $2.4^{48}$ & \\
\hline Veracruz & & & & $3.0^{48}$ & $3.1^{67}$ \\
\hline \multirow[t]{2}{*}{ Yucatán } & & & $1.2^{61}$ & $19.0^{68}$ & \\
\hline & & & & $1.5^{48}$ & \\
\hline Zacatecas & & $13.0^{70}$ & & $2.4^{48}$ & \\
\hline
\end{tabular}

Table II

Seroprevalence of infected blood Samples in Mexican blood banks

\begin{tabular}{lrl} 
State & Seroprevalence of infection (\%) & Reference \\
Jalisco & $1.3-8.7$ & 71,72 \\
\hline México, D.F. & 0.3 & 73 \\
\hline Morelos & 17.0 & 74 \\
\hline Puebla & 17.5 & 33 \\
\hline Yucatán & 5.6 & 75
\end{tabular}


a single diagnosis method and have thus to be interpreted with caution. Nonetheless, they all point out significant risks of transfusion-associated transmission of T. cruzi. Despite these risks, screening of blood samples for T. cruzi seropositivity is still not systematic, and there are currently no specific policies from health agencies in Mexico.

An important point that also needs to be emphasized is the difference between infection and disease. As mentioned above, studies in South American countries indicated that about $30-40 \%$ of infected patients develop a chronic chagasic disease (cardiomyopathy or megasyndromes). Very few epidemiological data are available for the incidence of the chronic disease in Mexico. ${ }^{69}$ Some isolated cases have been described in different states ${ }^{47,49-51,69}$ and, in the past five years, health authorities reported a total of 441 new cases of chronic chagasic cardiomyopathy. ${ }^{52}$ As pointed out previously by other authors, ${ }^{53}$ the fact that few chronic cases are reported in Mexico despite the endemicity of T. cruzi parasites in vectors and reservoirs and the relatively high seroprevalence in humans may be due to a low virulence of the Mexican strains of T. cruzi, or to the lack of detection of the existing cases.

Several studies of the biological characteristics of Mexican strains of T. cruzi have been initiated. From a phylogenetic point of view, they present a high genetic variability but appear clearly distinct from the strains encountered in other regions, ${ }^{54-56}$ which confirms the need for a regional approach in studying this parasite. However, the relationship between genotypes and biological characteristics such as infectivity and virulence is still debated and not clearly understood. ${ }^{57-59}$ The direct assessment of infectivity and virulence of Mexican strains in vitro and in vivo also indicated an important variability between strains, but their overall virulence appears comparable to that found in strains from other regions $s^{55-56}$ Barrera-Perez, unpublished results). These observations appear to point out the existence of T. cruzi strains in Mexico well able to induce chronic chagasic cardiomyopathy. However, it is not known how the interactions of these T. cruzi strains with local species of insect vector and mammalian reservoirs may affect their intrinsic virulence.

On the other hand, it seems very likely that a large number of cases go undetected, and the major increase in reported cases in the past few years ${ }^{52}$ may well reflect a better detection and diagnosis. Indeed, a recent survey indicated that $7 / 36$ (i.e. $17 \%$ ) of heart disease patients from a local hospital in Yucatan suffered from chagasic cardiomyopathy. ${ }^{60}$ In Mexico, another study indicated that $21 / 40$ (i.e. $52 \%$ ) patients with dilated cardiomyopathy were seropositive for T. cruzi. $^{13}$ It is of course difficult to extrapolate from these limited data, but they suggest nonetheless that a very large fraction of the heart disease cases observed in Mexico today may be related to T. cruzi infection, and the main problem may therefore rely in the correct detection of these cases.

\section{Future prospects}

Despite the wide heterogeneity of the studies performed in Mexico, they clearly demonstrate that Chagas' disease is present in various areas of the country, and the main vector and reservoir species have been identified. Chronic chagasic cardiomyopathy may be affecting a large number of patients with heart disease, but many cases may be misreported because of the unspecific nature of the clinical symptoms. Despite these efforts to understand Chagas' disease in Mexico, and because of its very heterogeneous properties, much remains to be done for a complete assessment of this zoonosis. As clearly pointed out twenty years ago by a multidisciplinary study group ${ }^{61}$ and reaffirmed more recently at an OPS/WHO workshop, ${ }^{53}$ it is thus of key importance to further develop and intensify a reliable and complete epidemiological monitoring campaign of Chagas disease in Mexico. Such a monitoring campaign should not only cover clinical cases, with an accurate monitoring and diagnosis of patients in all three stages of the disease, to allow a better focus on Chagas' disease hot spots. Entomological surveillance and vector biology are also major areas that need to be developed, as vectors are the only targets of the control programs available to date. It is not known, for example, how these programs should be adapted to the variety of biological and ecological characteristics of vector species encountered in Mexico. More information on the biology and epidemiology of infection of identified reservoirs, which species are different from those reported in other countries, is also needed, as these reservoirs may influence the virulence of the parasite as well as its transmission. Finally, some efforts should also be dedicated to basic studies of T. cruzi biology, particularly the virulence of Mexican strains and the immune response they induce, as well as the search for alternative control strategies such as therapeutic treatments and vaccines. An effective organization, coordination and support of these research strategies is urgently needed from health and academic authorities to ensure that Mexico does not remain the only country endemic for Chagas' disease in the next century. 


\section{References}

1.W H O Progress 1995-1996:Thirteenth programme report of the UN DP/ World Bank/W HO Special Programme for Research and Training in Tropical D iseases, 1997; 112-123.

2.Minter D M. Manson's tropical diseases. 20th edition. London:W B Saunders Company, 1996; 1721-1730.

3.Guzmán-Marín E.Los transmisores de la enfermedad de Chagas. Rev Biomed 1990;1: 144-153.

4.Figueroa Damián R. Riesgos de transmisión enfermedades infecciosas por tranfusión. Ginecol 0 bstet Mex 1998;66: 277-283.

5.Schmuñis GA, Zicker F, Pinheiro F , Brandling-Bennett D. Risk for transfusion-transmitted infectious diseases in C entral and South America. Emerg Infec D is 1998;4: 5-11.

6. Schmuñis GA. Trypanosoma cruzi, the etiologic agent of Chagas' disease: Status in the blood supply in endemic and nonendemic countries. Transfusion 1991;31: 547-557

7. Gilson G J, Harner KA,A brams J, Izquierdo LA, C uret LB. C hagas disease in pregnancy. 0 bstet Gynecol 1995;86: 646-647.

8. Guzman-Bracho C, Lahuerta S, Velasco-Castrejón 0. Chagas disease. First congenital case report.Arch Med Res 1998;29: 195-196.

9. Marsden P D. Manson's tropical diseases. 20th edition. London:W B Saunders Company, 1996; 1197-1212.

10. Parada H, Carrasco HA, Anez N, Fuenmayor C, Inglessis I. Cardiac involvement is a constant finding in acute Chagas' disease:A clinical, parasitological and histopathological study. Int J Cardiol 1997;60: 49-54.

11. Carrasco H A,Alarcón M, O Imos L, Burguera J, Burguera M, Dipaolo A, et al. Biochemical characterization of myocardial damage in chronic $C$ hagas' disease. Clin Cardiol 1997;20: 865-869.

12. Bestetti R B , Muccillo G. C linical course of Chagas' heart disease:A comparison with dilated cardiomyopathy. Int J Cardiol 1997;60: 187-193. 13. Montenegro-Valdovinos PC, D e Micheli A , Reyes-López PA. Hallazgos electrovectorcardiográficos en la miocardio patia chagásica crónica. Arch Inst Cardiol Mex 1998;68: 51-57.

14. Berra H, C arnevali F, Revelli S, Moreno H, Maris Pezzotto S, Morini J C, et al. Electrocardiographic alterations in chronically Trypanosoma cruzi- infected persons exposed to cardiovascular factors.Arch Med Res 1998;29: 241-246.

15. C unha-N eto E, C oelho V, Guilherme L, Fiorelli A, Stolf N , Kalii J.Autoimmunity in Chagas' disease: Identification of cardiac myosin-B13 Trypanosoma cruzi protein crossreactiveT cell clones in heart lesions of a chronic Chagas' cardiopathy patient.J Clin Invest 1996;98: 1709-1712.

16. Ferrari I, Levin MJ, W allukat $G$, Elies $R$, Lebesgue $D, C$ hiale $P$, et al. Molecular mimicry between the immunodominant ribosomal protein $\mathrm{PO}$ of Trypanosoma cruzi and a functional epitope on the human beta 1-adrenergic receptor. J Exp Med 1995;182: 59-65.

17. Vermelho $A B$, de Meirelles $M d N$, Pereira MC, Pohlentz $G$, BarretoBergter E. Heart muscle cells share common neutral glycosphingolipids with Trypanosoma cruzi.ActaTrop 1997;64: 131-143.

18. Baig MK, Salomone O, Caforio AL, Goldman JH, A muchastegui M, $C$ aiero $T$ et al. Human chagasic disease is not associated with an antiheart humoral response.Am J Cardiol 1997;79: 1135-1137.

19. Kalil J , Cunha-N eto E.Autoimmunity in Chagas disease cardiomyopathy: Fulfilling the criteria at last? Parasitol Today 1996;12: 396-399.

20. U rbina J A, Payares G, Molina J, Sanoja C , Liando A, Lazardi K et al. Cure of short- and long-term experimental Chagas' disease using $D 0870$. Science 1996;273: 969-971.

21. U rbina J A, Payares G, Contreras L M, Liendo A, Sanoja C, Molina J et al. Antiproliferative effects and mechanism of action of SCH 56592 against Trypanosoma (Schizotrypanum) cruzi: in vitro and in vivo studies. Antimicrob Agents Chemother 1998:42: 1771-1777.
22. Kinnamon KE, Poon BT, Hanson W H ,W aits VB. Activity of anticancer compounds agaisnt Trypanosoma cruzi-infected mice. Am J Trop Med Hyg 1998;58:804-806.

23. Liendo A, Lazardi K, U rbina JA. In-vitro antiproliferative effects and mechanism of action of the bis- triazole D 0870 and its S(-) enantiomer against Trypanosoma cruzi. J Antimicrob Chemother 1998;41:197-205.

24. Cinque GM, Szajnman SH, Zhong L, D ocampo R, Schvartzapel AJ, Rodriguez JB et al. Structure-activity relationship of new growth inhibitors of Trypanosoma cruzi.J Med Chem 1998;41:1540-1554.

25. Reed S G. Immunology of Trypanosoma cruzi infections. Chem Immunol 1998;70:124-143.

26. Gazzinelli RT, Talvani A, Camargo MM, Santiago HC, O liveira MA, Vieira $L Q$ et al. Induction of cell-mediated immunity during early stages of infection with intracellular protozoa. Braz J Med Biol Res 1998;31: 89-104.

27. Schofield CJ. Vector population responses to control interventions. Ann Soc Belg Med Trop 1991;71 suppl 1:201-217.

28. Marsden P, Garcia-Zapata MT, C astillo EA, Prata AR , Macedo VO. Los 13 primeros años del control de la enfermedad de Chagas en Mambai, Goias, Brasil, 1980-1992. Bol 0 ficina Sanit Panam 1994;116: 111-117.

29. Zerba EN, W allace G, Picollo M I, C asabe N, de Licastro S,W ood E, et al. Evaluación de la ß-cipermetrina para el control de Triatoma infestans. Rev Panam Salud Publica 1997:1:133-137.

30.W HO .U ruguay declared free of Chagas' disease transmission. TDR news 1998:56: 6.

31. Tay J, Schenone H, Sanchez JT, Robert L. Estado actual de los conocimientos sobre la enfermedad de Chagas en la Republica Mexicana. Bol Chil Parasitol 1992;47:43-53.

32. Vallejo AM, Reyes PA.Tripanosomiasis americana: iun problema sociomédico en México? Arch Inst Cardio Mex 1996;66: 95-97.

33.Velasco Castrejon 0, Guzmán Bracho C. Importancia de la enfermedad de Chagas en Mexico. Rev Latinoam Microbiol 1986;28:275-283.

34. G oldsmith R, Kegan L, Zárate R, Reyes-González M , C edeño J. Estudios epidemiológicos de la enfermedad de $C$ hagas en 0 axaca México. Bol Sanit Pan 1979;87: 1-17.

35. Tay J, de Biagi AM. Localidades nuevas de triatominos mexicanos y su infección natural por Trypanosoma cruzi. Rev Fac Med (Mex) 1964;6: 305311.

36. Guzmán-Marín ES, Barrera-Pérez MA, Rodríguez-Felix ME, ZavalaVelázquez JE. Hábitos biológicos de Triatoma dimidiata en el estado de Yucatán, México. Rev Biomed 1992;3:125-131.

37. Magallón-G astélum E, Magdaleno-Peñaloza NC, Katthain-D uchateau G, Trujillo-Contreras F, Lozano-Kasten FJ , Hernández-Gutiérrez R J. D istribución de los vectores de la enfermedad de Chagas (Hemiptera: Reduviidae: Triatominae), en el estado de Jalisco, México. Rev Biomed 1998;9: 151-157.

38. Cortés--liménez M, N ogueda-Torres B, Alejandre-A guilar R, Isita-Tornell L, Ramírez-Moreno E. Frequency of triatomines infected with Trypanosoma cruzi collected in Cuernavaca city, Morelos, Mexico. Rev Latinoam Microbiol 1996;38: 115-119.

39. Q uintal RE , Polanco G. Feeding preferences of Triatoma dimidiata maculipennis in Yucatan, Mexico.Am J Trop Med Hyg 1977;26: 176-178.

40. Green-Zárate L, Zárate-Castañeda R. The biology and behaviour of Triatoma barberi (Hemipterae:Reduviidae) in Mexico. I. Blood sources and infection with Trypanosoma cruzi.J Med Entomol 1980;17: 103-116.

41.Tay-Zavala, J, Sánchez-Vega JT, Robert-Guerrero L,Alonso-Guerrero T, Romero-C abello R. N uevas localidades con triatominos infectados por Trypanosoma cruzi en la República Mexicana. Bol Chil Parasitol 1996;51: 49-53.

42. D omínquez Vázquez A, Ricárdez Esquinca JR, Espinoza Medinilla E. Estudio de reservorios silvestres del Trypanosoma cruzi en la reserva ecoló gica de “El Zapotal", Chiapas, México. Bol Chil Parasitol 1990;45: 3-8. 
43. G alaviz-Silva L,Arredondo-C antú JM. Primer reporte de Neotoma micropus (Rodentia) como reservorio de Trypanosoma cruzi en Mexico. Bol Chil Parasitol 1992;47: 54-57.

44.Zavala-Velázquez J,Barrera-Pérez M, Rodríguez-Felix ME, Guzmán-Marín E, Ruiz-Piña H. Infection by Trypanosoma cruzi in mammals in Yucatan, Mexico: a serological and parasitological strudy. Rev Inst Med Trop Sao Paulo 1996;38: 289-292.

45. Ruiz-Piña H A, Abán-C auich AS, Rosado-Barrera ME, Arjona-Torres AD, Mendoza-C amargo LA. N atural infection by Trypanosoma cruzi in Didelphis virginiana in Yucatan, Mexico. Proc Seventh Int Theriological Congress, A capulco, Mexico 1997: 286.

46. Schofield C J. Control of Chagas' disease vectors. Br Med Bull 1985;41: 187-194.

47. Pérez-Fuentes $R$, Sánchez-G uillén $M C$, G onzález-Alvarez $C$, Monteón VM, Reyes PA, Rosales-Encina JL. Humoral nitric oxide levels and antibody immune response of symptomatic and indeterminate Chagas' disease patients to commercial and autochthonous Trypanosoma cruzi antigen.Am J Trop Med Hyg 1998;58: 715-720.

48.Velasco C astrejón O,Valdespino JL,Tapia C onyer R,Salvatierra B,Guzmán Bracho $C$, Magos $C$ et al. Seroepidemiologia de la enfermedad de $C$ hagas en Mexico. Salud Publica Mex 1992;34: 186-196.

49. Huante-Magaña R, Piza-Bernal R, Tabárez-Hernández J, Liera-Romero F, Mata-Carbajal E, Matadamas N. Enfermedad de Chagas en Guerrero. Reporte de dos casos confirmados con xenodiagnósticos. Sal Publica Mex 1990;32: 320-324.

50. Salazar-Schettino P M, Ruiz-Hernández A L, Haro-Artega I,Tay-Zavala J, Gutiérrez-Q uiroz M. Serología y electrocardiografía en jóvenes de área endémica de enfermedad de Chagas. Rev Med IMSS (Mex) 1989;27:59-65. 51. Cortez JM, González-Hermosillo JA, Reyes PA, Martínez-Ríos MA,Velazco-Castrejón 0, De la Torre R. Cardiomiopatía chagásica en México. Arch Inst Cardiol Mex 1986;56: 499-505.

52.Velázquez 0,0 rtiz G, Tapia R. Perspectivas para el control y vigilancia epidemiológica de la enfermedad de Chagas un el país. Memorias del XIII Congreso N acional de Parasitología, Zacatecas, 1998:35.

53. 0 rtega-Pierres $G$, López-Antuñano FJ.Taller internacional sobre epidemiología molecular. Propuestas del grupo interdisciplinario sobre Trypanosomiasis A mericana y Leishmaniosis. Gac Med Mex 1997;133 suppl 1: 49-62.

54. Z avala-C astro JE,Velasco-C astrejón 0, Hernández R. Molecular characterization of Mexican stocks of Trypanosoma cruzi using total D N A.Am J Trop Med Hyg 1992;47: 201-209.

55. López-O Imos V, Pérez-N asser $N$, Pinero $D, O$ rtega $E$, Hernández $R$, Espinoza B. Biological characterization and genetic diversity of Mexican isolates of Trypanosoma cruzi.Acta Trop 1998;69: 239-254.

56. Espinoza B,Vera-C ruz JM, G onzález H, 0 rtega E , Hernández R. G enotype and virulence correlation within Mexican stocks of Trypanosoma cruzi isolated from patients. Acta Trop 1998;70: 63-72.

57. Lauria-Pires L,TeixeiraARL.Virulence and pathogenicity associated with diversity of Trypanosoma cruzi stocks and clones derived from Chagas' disease patients.Am J Trop Med Hyg 1996;55: 304-310.

58. Solari A,W allace A, 0 rtiz S,Venegas J, Sánchez G . Biological characterization of Trypanosoma cruzi stocks from Chilean insect vectors. Exp Parasitol 1998;89: 312-322.

59. Revollo S, O ury B, Laurent J P, Barnabe C, Q uesney V, C arriere V et al. Trypanosoma cruzi: Impact of clonal evolution of the parasite on its biological and medical properties. Exp Parasitol 1998;89: 30-9.
60.Zavala-C astro JE, Gutiérrez-Flota H, Barrera-Pérez M A, Bolio-Solís DJ, Zavala-Velázquez JE. C adio patía chagásica detectada en pacientes del hospital general regional 0 'H oran, Mérida,Yucatán, México.Arch Inst C ardiol Mex 1995;65:541-545.

61. G rupo de Estudio. Enfermedad de Chagas en México, San C ristóbal de las C asas, México, Centro de Investigaciones Ecológicas del Sureste, 1978. 62.Andersson N , Morales A, N ava E, Martínez E, Rodríguez I,Young P et al. Trypanosoma cruzi infection in the Mexican state of Guerrero: a seroepidemiological (ELISA) survey of 20 communities. JTrop Med Hyg 1990;93: 341-346.

63.Tay J, Biagi F, B de Biagi A. Estado actual del conocimientos sobre triatomas y enfermedad de $C$ hagas en el estado de Michoacán, México. Rev Fac Med (Mex) 1967;9:109-121.

64.Torres CM, Guerrero S, Román 0, G uzmán-Bracho C. La urbanización de áreas rurales como factor de riesgo para la infección por Trypanosoma cruzi. Memorias del XIII Congreso N acional de Parasitología, 1998:26-27. 65. Cortés J,Velazco 0, Labastida M, Melchor A, D uarte N, De Torre R. La enfermedad de Chagas en Santiago Yosotiche, 0 axaca, México. Salud Publica Mex 1985;27:60-65.

66. G oldsmith R, Zárate R, Zárate L, Kegan L, Jacobson L, Morales G. Estudios clínicos y epidemiológicos de la enfermedad de Chagas en 0 axaca, México, y un estudio complementario de siete años en Cerro del Aire. Bol Sanit Pan 1986;100:145-169.

67. Ruiz-Hernández A L, Bucio-Torres MI, Salazar-Schettino PM. Estudio epidemiológico de la enfermedad de Chagas en el estado de Veracruz. Memorias del XIII Congresso Nacional de Parasitología, 1998: 17.

68. Farfán-Ale JA, Loroño-Pino MA, Flores-Flores LF, Rosado-Parades EP, Arjona-Torres A. Prevalencia de anticuerpos contra Toxoplasma gondii y Tripanosoma cruzi en el estado de Yucatán. Rev Biomed 1992;3: 8-12. 69. Barrera-Pérez MA, Rodríguez-Felix ME, Guzmán-Marín E, Zavala-Velazquez JE. Prevalencia de la enfermedad de Chagas en el estado deYucatán. Rev Biomed 1992:3: 133-139.

70.Tay J, Biagi F, B de Biagi A. Estado actual de conocimientos so bre triatomas y enfermedad de Chagas en el estado de Zacatecas. Rev Fac Med (Mex) 1968:48: 121-129.

71.Trujillo Contreras F, Lozano Kasten F, Soto Gutiérrez MM, Hernández Gutiérrez R. Prevalencia de infección a Trypanosoma cruzi en donadores de sangre en el Estado de Jalisco, México. Rev Soc Bras Med Trop 1993;26: 89-92.

72. Campos VG, Sánchez LR, Jiménez CE, J. CR, Romero P. Anticuerpo anti-Trypanosoma cruzi en bancos de sangre del centro Médico $\mathrm{N}$ acional del 0 ccidente, IMSS, Guadalajara, Jal. Memorias del XIII Congresso N acional de Parasitología 1998:16-17.

73. Ramos Echevarría AA, Monteón Padilla VM, Reyes López PA. Deteccion de anticuerpos contra Trypanosoma cruzi en donadores de sangre. Salud Publica Mex 1993:35: 56-64.

74. Rangel H, Gatica R, Ramos C. D etection of antibodies against Trypanosoma cruzi in donors from a blood bank in Cuernavaca, Morelos, Mexico. Arch Med Res 1998:29:79-82.

75. Rodríguez-Felix ME, Zavala-Velázquez J, Barrera-Pérez MA, GuzmánMarín E, Ramírez-Sierra MJ,Alvarez-Moguel R. Riesgo de transmisión de la enfermedad de Chagas por donante de sangre. Rev Biomédica 1995;6: 70-75. 